\title{
Pengaruh penerapan carbohydrate loading modifikasi terhadap kesegaran jasmani atlet sepak bola
}

\author{
Bayu Febri Utoro ${ }^{1}$, Fillah Fithra Dieny ${ }^{2}$
}

\begin{abstract}
Background: The reduction of glycogen stores gradually during sports activities affect the performance of athletes. Carbohydrate loading is a method that aims to increase the glycogen stores are expected to delay fatigue and prevent hypoglycemia at the time of the match

Purpose: The purpose of this study was to verify the effect of modification carbohydrate loading to the physical fitness and some indicators of nutritional status soccer athletes

Methods: Experimental studies with approaches one group pre and post test design on 23 athletes aged 14-20 years in Diklat Sepak Bola Bintang Pelajar Semarang Regency in July 2011. During one week the subjects were given a high carbohydrate intake approximately $70 \%$ of the total energy requirement (protein and fat are given to normal) and soccer practice programmed with moderate intensity in the first three days and continued the intensity of light at the second of three days. Measurements included weight, height, percent body fat, lean body mass, blood glucose levels and physical fitness with Asian Committee on the Standarization of Physical Fitness Test (ACSPFT) method

Results: There were significant differences of physical fitness, physical fitness components (speed and cardiorespiratory endurance), body mass index, percent fat, lean body mass and blood glucose levels before and after treatment with $p<0.05$

Conclusion: Modified carbohydrate loading effected on physical fitness of soccer athletes. Fat mass and lean body mass to be the most influence factors on physical fitness
\end{abstract}

Keywords: carbohydrate loading modification, physical fitness, soccer athletes

\begin{abstract}
ABSTRAK
Latar Belakang: Penurunan simpanan glikogen secara bertahap selama melakukan aktivitas olahraga berpengaruh terhadap performa atlet. Carbohydrate loading merupakan suatu metode yang bertujuan untuk meningkatkan simpanan glikogen yang diharapkan dapat menunda kelelahan serta mencegah hipoglikemia pada saat dilakukannya pertandingan

Tujuan: Menganalisa pengaruh penerapan carbohydrate loading modifikasi terhadap kesegaran jasmani atlet sepak bola dan beberapa indikator status gizi

Metode: Studi eksperimental dengan pendekatan one group pre and post test design pada 23 atlet usia 14-20 tahun di Diklat Sepak Bola Bintang Pelajar Kabupaten Semarang bulan Juli 2011. Selama satu minggu subjek diberikan asupan tinggi karbohidrat kurang lebih 70\% dari total kebutuhan energi (kebutuhan protein dan lemak diberikan normal) dan latihan sepak bola terprogram dengan intensitas sedang pada tiga hari pertama dan dilanjutkan intensitas ringan pada tiga hari kedua. Pengukuran yang dilakukan meliputi berat badan, tinggi badan, persen lemak tubuh, massa tubuh tanpa lemak, kadar glukosa darah dan kesegaran jasmani dengan metode Asian Committee on the Standarization of Physical Fitness Test (ACSPFT)

Hasil: Terdapat perbedaan bermakna pada kesegaran jasmani, komponen kesegaran jasmani (kecepatan dan daya tahan kardiorespirasi), indeks massa tubuh, persen lemak, massa tubuh tanpa lemak dan kadar glukosa darah sebelum dan setelah perlakuan dengan $p<0,05$

Kesimpulan: Penerapan carbohydrate loading modifikasi berpengaruh terhadap kesegaran jasmani atlet sepak bola. Persen lemak dan massa tubuh tanpe lemak menjadi faktor yang paling berpengaruh terhadap kesegaran jasmani
\end{abstract}

Kata Kunci: carbohydrate loading modifikasi, kesegaran jasmani, atlet sepak bola

\section{PENDAHULUAN}

Sepak bola merupakan olahraga beregu atau tim yang membutuhkan ketrampilan yang berhubungan dengan kesegaran jasmani yaitu kekuatan otot, kecepatan, kelincahan dan membutuhkan energi tinggi dalam pelaksanaannya. Atlet sepak bola membutuhkan pemenuhan energi mencapai 3800-3900 kalori tiap

1. Quality Control, Mayora, Indonesia

2. Departemen Ilmu Gizi, Fakultas Kedokteran Universitas Diponegoro, email : korespondesi fillahdieny@gmail.com hari. ${ }^{1}$ Perbandingan pemakaian energi anaerobik dan aerobik pada sepak bola yaitu sebesar 70:30. Energi anaerobik digunakan untuk menunjang aktivitas dengan durasi pendek namun dengan intensitas kuat seperti lari cepat, melompat, melempar bola. ${ }^{2}$ Energi aerobik ditujukan untuk aktivitas dengan durasi panjang namun mempunyai intensitas rendah seperti jogging dan terutama ditujukan untuk pemulihan tenaga diantara aktivitas anerobik. ${ }^{1,2}$ Pemenuhan kebutuhan gizi pada atlet sepak bola seringkali dijumpai berada pada kategori kurang, seperti yang tergambarkan pada penelitian atlet sepak bola di Kota Pasuruan, Bantul dan Yogyakarta. ${ }^{3}$ Pemenuhan 
kebutuhan gizi atlet sepak bola harus memperhatikan posisi pemain. Seorang pemain gelandang (tengah) mempunyai jarak tempuh yang lebih tinggi dari pada pemain lainnya saat bertanding. ${ }^{1}$ Penelitian yang lain menunjukkan bahwa sebanyak 79,6\% siswa Sekolah Sepak Bola (SSB) di Malang memiliki kesegaran jasmani dengan kategori rendah dan sangat rendah. ${ }^{4}$ Penelitian pada atlet sepak bola profesional PSIS Semarang terdapat $42,2 \%$ atlet mempunyai kesegaran jasmani dengan kategori sedang, kurang dan kurang sekali. ${ }^{5}$ Latihan terprogram dan pemberian asupan gizi sesuai kebutuhan atlet menjadi unsur yang cukup penting dalam pembinaan sepak bola usia muda, selain berguna untuk mengoptimalkan pertumbuhan juga ditujukan untuk menyiapkan kondisi terbaik atlet, baik sebelum, saat dan setelah pertandingan berlangsung. Faktor gizi menjadi bagian science support dalam rangka mewujudkan prestasi sepak bola. ${ }^{29}$

Diharapkan pembinaan sepak bola dengan sistem asrama dapat memberikan asupan gizi yang terpantau dan program pembinaan serta latihan fisik yang tersusun dengan baik sehingga dapat terwujud kesegaran jasmani atlet dengan kategori baik. ${ }^{12}$ Salah satu penyelenggara diklat sepak bola di kota Salatiga yaitu Diklat Sepak Bola Bintang Pelajar Kabupaten Semarang, telah memiliki program pembinaan yang baik. Hal tersebut tercermin dari prestasi yang didapatkan oleh Diklat Bintang Pelajar dalam kurun waktu lima tahun terakhir yaitu Juara I Pekan Olahraga Pelajar Daerah Jawa Tengah tahun 2007, Juara I nasional Pospenas tahun 2009, di tahun yang sama Diklat Bintang Pelajar juga menjadi juara I Liga Remaja U-15 Jawa Tengah. Pada tahun 2010 berhasil didapatkan dua prestasi yaitu Juara III Pekan Olahraga Nasional di Yogyakarta dan Juara II Pospenas di Surabaya. Kesegaran jasmani pemain sepak bola Diklat Bintang Pelajar memiliki kategori baik namun di lain sisi belum menerapkan manajemen penyelenggaraan makanan atlet dengan optimal. ${ }^{12}$

Kesegaran jasmani merupakan kemampuan untuk melakukan kegiatan atau pekerjaan sehari-hari dan adaptasi terhadap perubahan fisik tanpa menimbulkan kelelahan berlebih. ${ }^{6,28}$ Kesegaran Jasmani atlet sepak bola sangat dibutuhkan karena atlet sepak bola harus bermain $2 \times 45$ menit. Terdapat keterkaitan antara status gizi dan aktivitas fisik terhadap kesegaran jasmani atlet sepak bola. ${ }^{5}$

Metabolisme energi atlet olahraga beregu (sepak bola) berjalan secara simultan melalui metabolisme secara aerobik maupun anaerobik. Karbohidrat akan memberikan kontribusi yang lebih besar dibandingkan dengan simpanan lemak untuk menghasilkan energi dalam olahraga beregu. Simpanan glikogen di dalam tubuh makin berkurang jika aktivitas fisik yang dilakukan tidak diimbangi dengan pemenuhan kebutuhan gizi. Seorang atlet dengan simpanan glikogen rendah memiliki jarak tempuh pendek dan kemampuan sprint yang lambat dari pada atlet dengan simpanan glikogen normal. ${ }^{9}$ Carbohydrate loading merupakan suatu metode yang bertujuan untuk meningkatkan simpanan glikogen dengan harapan dapat menunda kelelahan serta mencegah hipoglikemia pada saat dilakukannya pertandingan. ${ }^{10}$ Modifikasi carbohydrate loading merupakan cara yang dapat ditempuh untuk mengurangi efek samping penerapan carbohydrate loading asli, yaitu dengan menghilangkan fase latihan yang berat serta pembatasan asupan karbohidrat di awal program. Enam hari sebelum pertandingan diberikan makanan dengan tinggi karbohidrat (70\% dari total energi) sementara kebutuhan protein dan lemak diberikan dengan persentase normal yaitu 5-15\% untuk protein dan 10-20\% lemak. Selain pemenuhan asupan tinggi karbohidrat, metode carbohydrate loading modifikasi juga diikuti dengan latihan sepak bola terprogram yaitu yang latihan intensitas sedang pada tiga hari pertama dan intensitas ringan pada tiga hari kedua. Program carbohydrate loading modifikasi dapat meningkatkan konsentrasi glikogen otot diperoleh sebesar $130-205 \mathrm{mmol} / \mathrm{kg}$ berat badan dibandingkan dengan $80-212 \mathrm{mmol} / \mathrm{kg}$ barat badan dengan cara asli. Selain itu penghilangan latihan yang keras dan pembatasan karbohidrat pada awal program akan menurunkan risiko luka dan efek samping seperti kelelahan, mual, ketosis, berat badan menurun, pengeluaran sodium dan air meningkat. ${ }^{1,10}$

Peningkatan asupan karbohidrat terbukti dapat meningkatkan jarak tempuh lari pada atlet sepak bola PSS Yogyakarta. ${ }^{11}$ Terdapat peningkatan jarak tempuh sebesar 26\% pada atlet lari yang diberikan asupan tinggi karbohidrat. ${ }^{8}$ Asupan tinggi karbohidrat yang diberikan setelah 30 menit berlatih terbukti dapat meningkatkan kemampuan fisik dan fisiologis atlet sepak bola setelah 16 jam pertandingan sepak bola. ${ }^{26}$

Tujuan penelitian ini secara umum adalah membuktikan dan menganalisa pengaruh penerapan carbohydrate loading modifikasi terhadap kesegaran jasmani atlet sepak bola, komponen kesegaran jasmani (kecepatan, daya ledak otot dan daya tahan kardiorespirasi), indeks massa tubuh (IMT), persen lemak tubuh, massa tubuh tanpa lemak, dan kadar glukosa darah. Penelitian ini diharapkan dapat melengkapi penelitian terdahulu tentang pengaruh penerapan carbohydrate loading terhadap kesegaran jasmani atlet sepak bola serta dapat menjadi tambahan informasi bagi masyarakat, khususnya dalam bidang olahraga dan gizi.

\section{BAHAN DAN METODE}

Penelitian dilakukan di Diklat Sepak Bola Bintang Pelajar Kabupaten Semarang pada bulan Juli 
2011. Penelitian ini merupakan penelitian eksperimental dengan pendekatan one group pre and post test design dan termasuk dalam ruang lingkup gizi masyarakat. Subjek penelitian adalah atlet sepak bola yang diambil dengan cara consecutive sampling, yaitu subjek penelitian yang memenuhi kriteria dimasukkan dalam penelitian hingga jumlah subjek yang diperlukan terpenuhi. Kriteria inklusi dalam penelitian ini yaitu subjek berusia 14-20 tahun yang berada di Diklat Sepak Bola Bintang Pelajar Kabupaten Semarang, mempunyai kadar glukosa darah sewaktu normal yaitu $80-120 \mathrm{mg} / \mathrm{dL}$, tidak mengalami anemia yang ditandai dengan hasil pengukuran kadar hemoglobin $\geq 13 \mathrm{~g} / \mathrm{dL}$, tidak mengkonsumsi alkohol serta bersedia mengikuti keseluruhan rangkaian penelitian melalui persetujuan informed consent. Jumlah sampel minimal yang diperlukan untuk penelitian ini adalah 21 orang, yang dihitung menggunakan rumus perhitungan jumlah subjek untuk uji hipotesis beda rata-rata berpasangan.

Variabel bebas pada penelitian ini adalah penerapan metode carbohydrate loading modifikasi. Carbohydrate loading yang dimodifikasi terdiri dari pemberian asupan makanan dengan syarat tinggi karbohidrat yaitu 70-80\% dari total kebutuhan energi (protein dan lemak diberikan dengan persentase normal yaitu 5-15\% untuk protein dan 10-20\% lemak). Asupan makanan tinggi karbohidrat diberikan dengan tiga kali pemberian makanan besar dan tiga kali snack. Adapun perencanaan total asupan energi dan karbohidrat yang diberikan selama tujuh hari yaitu 1) Asupan sebesar 4050 kalori dengan 703 gram karbohidrat (69,42\%) 2) Asupan sebesar 4021 kalori dengan 707 gram karbohidrat (70,31\%) 3) Asupan sebesar 4032 kalori dengan 702 gram karbohidrat (69,63\%) 4) Asupan sebesar 4206 kalori dengan 742 gram karbohidrat (70,55\%) 5) Asupan sebesar 4025 kalori dengan 698 gram karbohidrat (69,36\%) 6) Asupan sebesar 3911 kalori dengan 692 gram karbohidrat (70,77\%) dan 7) Asupan sebesar 4402 kalori dengan 763 gram karbohidrat $(70,04 \%)$. Waktu pemberian makanan manyesuaikan dengan jadwal yang dimiliki oleh pengelola asrama. Latihan yang diberikan mengikuti program yang dijalankan oleh Diklat Bintang Pelajar. Selain itu juga dilakukan latihan sepak bola dengan intensitas sedang hingga berat pada tiga hari pertama dilanjutkan latihan dengan intensitas ringan hingga sedang pada tiga hari yang kedua, hari terakhir ditujukan untuk istirahat atau diberikan latihan dengan intensitas ringan. Setiap hari dilakukan dua kali latihan yaitu pada pagi hari pukul 05.00-06.00 WIB dan latihan sore dilakukan pukul 15.30-17.00 WIB. Program latihan yang diberikan berada pada tahap persiapan umum yang ditujukan untuk perbaikan performa fisik dan ketrampilan teknik atlet.
Variabel terikat pada penelitian ini adalah tingkat kesegaran jasmani atlet sepak bola yang dinilai menggunakan tes Asian Committee on the Standarization of Physical Fitness Test (ACSPFT). Tes ini merupakan satu rangkaian tes yang terdiri dari 7 jenis indikator yang menilai daya tahan kardiorespirasi, kecepatan, daya ledak otot, kekuatan statis dan daya tahan otot lengan/bahu, ketangkasan, daya tahan otot perut dan kelenturan. Hasil tes ini merupakan nilai kasar. Hasil kasar dari tiap-tiap jenis tes diubah menjadi nilai $t$ dengan mempergunakan tabel-T kemudian hasil yang ada dijumlahkan. Selanjutnya juga dilakukan analisa penerapan variabel bebas terhadap tiga indikator pada tes kesegaran jasmani yaitu : kecepatan, daya ledak otot, dan daya tahan kardiorespirasi. Kecepatan merupakan kemampuan tubuh untuk melakukan gerakan dengan menggunakan tenaga penuh dalam waktu sesingkat mungkin. Penilaian kecepatan dilakukan dengan lari 50 meter. Tujuan penilaian untuk mengukur kecepatan lari seseorang. Prinsip penilaian start dilakukan dengan berdiri kedua ujung kaki tepat pada garis start dan tidak boleh melebihi garis start setelah aba-aba kemudian lari secepat mungkin. Hasil yang dicatat adalah waktu yang dicapai untuk menempuh jarak sampai melewati garis finish. Waktu yang dicapai dihitung dengan tingkatan ketelitian 0,1 detik. Daya ledak otot dinilai dengan tes lompat jauh tanpa awalan dan hasil yang diperoleh adalah lompatan terjauh yang diukur dari garis batas permulaan lompatan ke titik terdekat sentuhan tumit pada tanah yang diukur pada saat pengumpulan data dan dinyatakan dalam sentimeter dengan kepekaan 0,1 $\mathrm{cm}$. Penilaian daya tahan kardiorespirasi merupakan kemampuan jantung dan paru-paru untuk menunjang sistem tenaga kerja otot. Penilaian daya tahan kardiorespirasi dilakukan dengan lari 1000 meter. Tujuan penilaian untuk mengukur daya tahan jantung dan paru-paru. Prinsip penilaian start dilakukan dengan berdiri dan ujung kaki sedekat mungkin dengan garis start dan tidak boleh melebihi garis start dan berlari dengan kecepatan penuh. Hasil yang dicatat adalah waktu yang dicapai untuk menempuh jarak tersebut samapai garis finish. Waktu yang dicapai dihitung dengan tingkat ketelitian 0,1 detik.

Penelitian dilakukan selama sembilan hari. Hari pertama dan kedua ditujukan untuk pengambilan data awal yaitu berupa survei asupan makanan, pengukuran antropometri (berat badan, tinggi badan, persen lemak tubuh, dan massa tubuh tanpa lemak), dan kadar hemoglobin. Hari ketiga dilakukan pengukuran kesegaran jasmani dan kadar glukosa darah (setelah melakukan tes kesegaran jasmani). Hari ketiga hingga kedelapan dilakukan penerapan carbohydrate loading modifikasi. Sementara pada hari kesembilan merupakan hari terakhir penerapan perlakuan dan dilakukan pengambilan data akhir berupa pengukuran 
antropometri (berat badan, persen lemak tubuh, massa tubuh tanpa lemak), kadar glukosa darah dan tes kesegaran jasmani.

Data yang dikumpulkan meliputi data identitas subjek penelitian, gambaran asupan, hasil pengukuran antropometri (berat badan, tinggi badan, persen lemak tubuh, massa tubuh tanpa lemak), kadar glukosa darah dan hemoglobin serta kesegaran jasmani menggunakan metode ACSPFT baik sebelum dan sesudah penerapan carbohydrate loading modifikasi. Pengukuran berat badan diperoleh dengan penimbangan menggunakan timbangan injak digital dengan ketelitian $0,1 \mathrm{~kg}$. Pengukuran tinggi badan didapat dengan menggunakan microtoise dengan ketelitian $0,1 \mathrm{~cm}$ dan panjang $2 \mathrm{~m}$. Gambaran asupan makan baik sebelum maupun selama perlakuan didapat dengan menggunakan formulir recall 24 jam dan pencatatan commstock. Persentase lemak tubuh diukur menggunakan Body Fat Analyzer Model HBF-356. Pengukuran kadar glukosa darah dan hemoglobin dilakukan oleh laboran dari Rumah Sakit Umum Ananda Kota Salatiga. Waktu yang diperlukan untuk menyelesaikan tes kesegaran jasmani yang telah ditentukan diukur menggunakan stopwatch dengan ketelitian 0,01 detik untuk pengukuran komponen kecepatan, ketangkasan dan daya tahan kardiorespirasi. Pita meter dengan ketelitian $0,1 \mathrm{~cm}$ untuk pengukuran komponen daya ledak otot. Dua buah penggaris dengan ketelitian $0,1 \mathrm{~cm}$ dan satu buah bangku untuk pengukuran komponen kelentukan. Kuesioner untuk mencatat hasil ukur komponen daya tahan otot lengan dan bahu dan daya tahan otot perut.

Analisa data dilakukan menggunakan program SPSS 16,0 for windows. Analisa univariate dilakukan untuk mendeskripsikan karakteristik subjek penelitian, yaitu umur, tinggi badan, berat badan, indeks massa tubuh (IMT), persen lemak tubu, massa tubuh tanpa lemak, kadar glukosa darah dan asupan energi serta tingkat kesegaran jasmani sebelum perlakuan. Analisa bivariate menggunakan uji beda untuk mengukur perubahan nilai baik pada indkes massa tubuh, persen lemak tubuh, massa tubuh tanpa lemak, kadar glukosa darah maupun kesegaran jasmani sebelum dan sesudah perlakuan. Analisa bivariate diawali dengan uji normalitas data Shapiro Wilk kemudian dilanjutkan dengan uji beda menggunakan paired t-test. Analisa multivariat ditujukan untuk mengetahui variabel yang paling berpengaruh terhadap kesegaran jasmani menggunakan regresi linier berganda. Kesegaran jasmani setelah perlakuan merupakan variabel terikat. Nilai indeks massa tubuh, persen lemak tubuh, massa tubuh tanpa lemak dan asupan karbohidrat menjadi variabel bebas. Data asupan energi diperoleh dari hasil food recall dan commstock selanjutnya data yang terkumpul dianalisa dengan bantuan program food processor III.

\section{HASIL}

Penelitian dilakukan di Diklat Sepak Bola Bintang Pelajar Kabupaten Semarang pada bulan Juli 2011. Subjek penelitian merupakan atlet sepak bola berusia 14-20 tahun yang berada di Diklat Bintang Pelajar. Sebanyak 31 orang bersedia menjadi subjek penelitian. Dari jumlah tersebut hanya 25 orang yang memiliki kriteria inklusi menjadi subjek penelitian. Selama penelitian, dua orang drop out karena tidak dapat mengikuti seluruh rangkaian penelitian.

\section{Karakteristik Subjek Penelitian}

Tabel 1. Karakteristik Subjek Penelitian Sebelum Intervensi

\begin{tabular}{lccc}
\hline Karakteristik Subjek & Minimal & Maksimal & Rerata \pm SD \\
\hline Usia (tahun) & 14,60 & 18,50 & $16,24 \pm 1,03$ \\
Asupan energi (kkal) & 2275 & 3235 & $2798 \pm 254$ \\
Asupan karbohidrat (gram) & 356 & 578 & $471,35 \pm 25,58$ \\
Tinggi badan (m) & 1,57 & 1,74 & $1,66 \pm 0,05$ \\
Berat badan (kg) & 43,30 & 69,90 & $57,20 \pm 7,38$ \\
Indeks massa tubuh (IMT) $\left(\mathrm{kg} / \mathrm{m}^{2}\right)$ & 16,89 & 23,09 & $20,57 \pm 1,77$ \\
Persen lemak (\%) & 6,10 & 17,70 & $11,64 \pm 2,71$ \\
Massa tubuh tanpa lemak (kg) & 39,19 & 60,53 & $50,41 \pm 5,71$ \\
Kesegaran Jasmani (Skor) & 400 & 492 & $449,57 \pm 25,58$ \\
\hline
\end{tabular}

Rerata usia subjek yaitu $16,24 \pm 1,03$ tahun dengan subjek termuda berusia 14,6 tahun dan tertua berusia 18,5 tahun. Keseluruhan subjek mempunyai kadar hemoglobin normal yaitu berada di atas $13 \mathrm{~g} / \mathrm{dl}$ dengan rerata $14,49 \pm 0,61 \mathrm{~g} / \mathrm{dl}$.

Rerata indeks massa tubuh (IMT) subjek adalah $20,57 \pm 1,77 \mathrm{~kg} / \mathrm{m}^{2}$. IMT maksimum yang didapatkan yakni $23,09 \mathrm{~kg} / \mathrm{m}^{2}$. Setelah disesuaikan kurva IMT sesuai umur (2-20 tahun) dan jenis kelamin didapatkan bahwa semua subjek berstatus gizi normal. Terdapat satu orang subjek dengan IMT $17,45 \mathrm{~kg} / \mathrm{m}^{2}$ dan usia 16,3 tahun mempunyai hasil ukur berada sedikit di atas persentil 5, sebagai batas bawah kategori status gizi normal. Pengukuran komposisi tubuh subjek yaitu persen lemak didapatkan rerata sebesar 11,64 \pm $2,71 \%$. Hasil pengukuran persen lemak 
mengindikasikan bahwa proporsi lemak tubuh subjek sesuai untuk seorang pemain sepak bola yaitu berada pada rentang 8-18 \%, dengan satu subjek berada di bawah normal $(6,10 \%)$ dengan nilai tertinggi persen lemak yaitu $17,70 \%$. Nilai massa tubuh tanpa lemak (lean body mass) subjek didapatkan dengan cara perhitungan, yaitu selisih antara berat badan aktual dengan persen lemak $(\%)$ dan didapatkan rerata sebesar $50,41 \pm 5,71 \mathrm{~kg}$.

Kebutuhan energi dihitung dengan mempertimbangkan kebutuhan energi basal, specific dynamic action (SDA), aktivitas fisik dan penambahan kalori untuk pertumbuhan sebesar $10 \%$. Selain latihan rutin sepak bola yang diselenggarakan sebanyak 12 kali dalam satu minggu. Mayoritas subjek mempunyai aktivitas fisik dengan tingkat ringan hingga sedang. Aktivitas fisik yang dilakukan subjek yaitu belajar baik di sekolah maupun di asrama, jogging, bermain futsal, dan beberapa aktivitas keseharian di asrama seperti menyapu kamar, mandi, mencuci pakaian dan melihat televisi. Hasil yang diperoleh kebutuhan energi subjek berkisar antara 3361 kalori hingga 4118 kalori.

Hasil recall asupan makanan yang dilakukan sebelum intervensi didapatkan rerata energi yang dikonsumsi subjek dalam sehari sebesar $2798 \pm 254$ kkal. Terdapat ketimpangan antara asupan yang dikonsumsi dengan kebutuhan yang diperlukan oleh subjek. Tiga subjek mempunyai kategori asupan defisit $(<70 \%)$, lima belas subjek mempunyai kategori asupan kurang (70-80\%) dan lima subjek dengan kategori asupan sedang (80-99\%) dari kebutuhan energi yang seharusnya dikonsumsi. Rerata asupan karbohidrat didapatkan sebesar 471,35 $\pm 59,28$ gram. Pencapaian konsumsi karbohidrat sebelum intervensi sebesar $50,50 \%$ dari total kebutuhan energi yang diperlukan. Terdapat empat orang subjek dengan kategori asupan karbohidrat baik (80-100\%) dan 19 subjek mempunyai kategori asupan karbohidrat rendah $(<80 \%)$.

Hasil pengukuran tingkat kesegaran jasmani sebelum perlakuan didapatkan rerata skor sebesar $449,57 \pm 25,58$ poin. Sebanyak 14 subjek memiliki kategori kesegaran jasmani baik sekali dengan skor lebih dari 431, dan 9 subjek dengan kategori kesegaran jasmani baik dengan skor antara 376 - 430.

\section{Penerapan Carbohydrate Loading Modifikasi}

Terdapat dua perlakuan yang diberikan terhadap subjek dalam penelitian ini yaitu pemberian asupan makanan dengan tinggi karbohidrat (70-80\% dari total kebutuhan energi) dan latihan terprogram yang diterapkan selama tujuh hari. Asupan tinggi karbohidrat dilakukan dengan pemberian tiga kali makanan utama dan tiga kali snack. Asupan utama diberikan pukul 06.15 WIB, 13.30 WIB, dan 18.00 WIB. Sementara snack diberikan pada pukul 06.15 WIB (sebagai bekal ke sekolah), setelah makan siang dan malam pada pukul 20.00 WIB masing-masing dengan dua jenis snack. Porsi nasi sebagai bahan makanan pokok yang diberikan sebesar 300 gram untuk setiap kali makan. Asupan tinggi karbohidrat juga diwujudkan melalui dua kali pemberian buah dan susu (untuk waktu makan pagi dan malam). Adapun pemilihan bahan makanan dan snack mempertimbangkan kandungan tinggi karbohidrat dalam bahan makanan.

Rerata asupan karbohidrat meningkat setelah intervensi yaitu mencapai $679,84 \pm 30,76$ gram dengan persentase pemenuhan dari total kalori yang diperlukan sebesar $69,48 \%$. Dua puluh dua subjek mempunyai kategori asupan karbohidrat lebih (>100\% angka kecukupan) dan satu subjek dengan kategori asupan baik. Terdapat peningkatan rerata asupan protein sebesar 25,65 gram. Rerata asupan lemak meningkat dari sebelumnya 71,4052 $\pm 4,75$ gram menjadi 72,3318 $\pm 0,97$ gram.

Latihan yang diberikan mengikuti program dari Diklat Bintang Pelajar. Program latihan berada pada tahap persiapan umum yang ditujukan untuk perbaikan kemampuan fisik dan ketrampilan teknik. Latihan dilakukan sebanyak 12 kali yang diselenggarakan pagi dan sore. Latihan pagi diadakan pukul 05.00 hingga 06.00 WIB sementara latihan sore diadakan pukul 15.30 hingga 17.00 WIB. Hari pertama hingga keenam latihan diberikan dengan intensitas sedang sementara pada hari ketujuh hanya dilakukan latihan pagi dengan intensitas ringan berupa pemanasan dan teknik dasar. Program latihan pagi berupa sprint jarak pendek, jogging di jalan raya dan shuttle run untuk meningkatkan kemampuan fisik sementara program latihan sore ditujukan untuk meningkatkan ketrampilan berupa latihan teknik dasar (passing, control, heading dan shooting) serta simulasi permainan. 


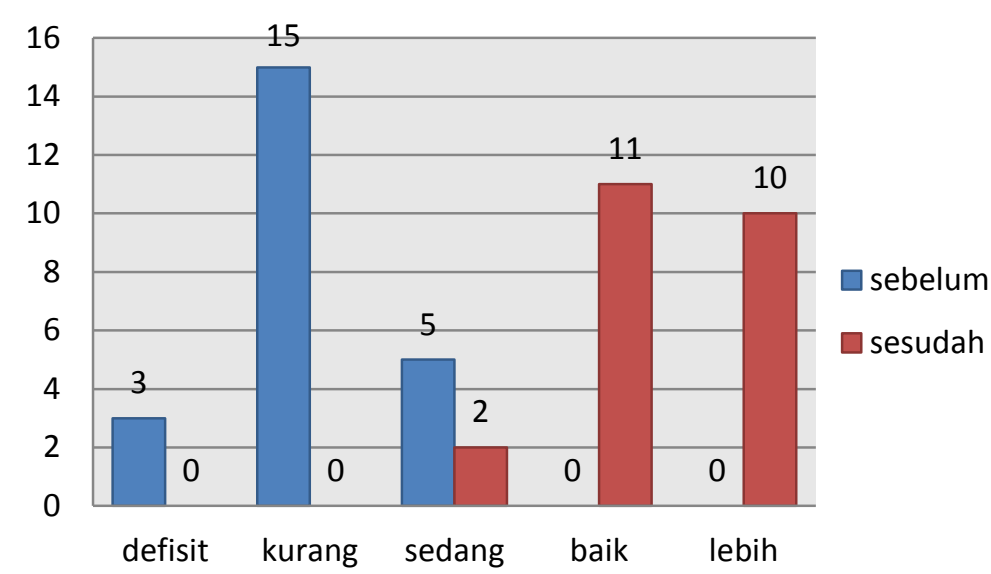

Grafik 1. Gambaran Asupan Energi Sebelum dan Setelah Perlakuan

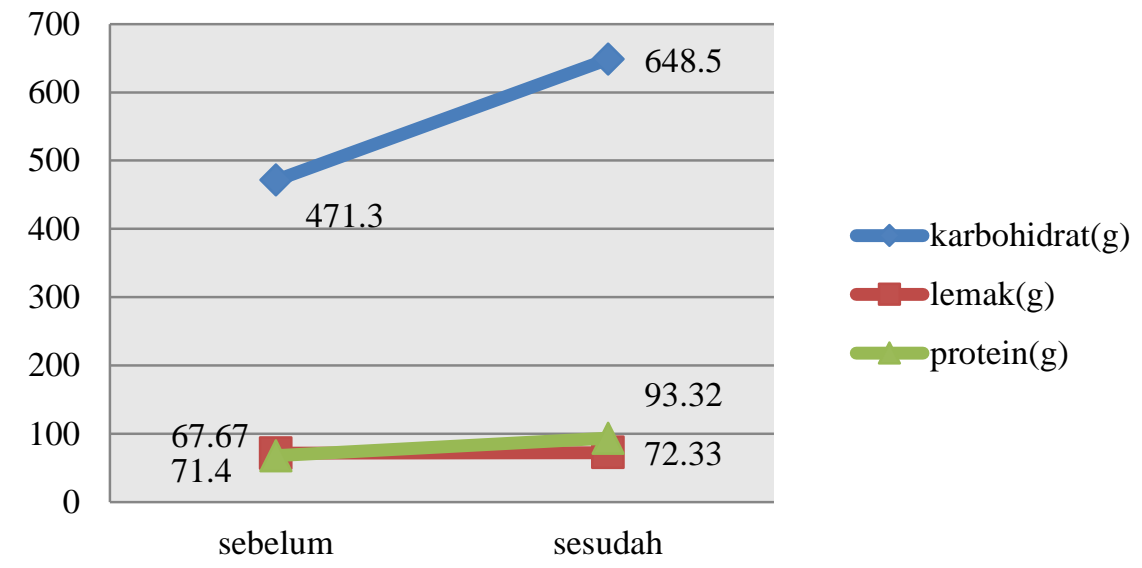

Grafik 2. Gambaran Asupan Zat Gizi Makro Sebelum dan Setelah Perlakuan

\section{Tingkat Kesegaran Jasmani Sebelum dan Setelah Perlakuan}

Tes kesegaran jasmani dilakukan pada sore hari, berlangsung sekitar 90 menit dan bertempat di lapangan sepak bola Semowo. Tes kesegaran jasmani menggunakan metode ACSPFT dilakukan berurutan mulai dari lari 50 meter, angkat badan, lari $4 \times 10$ meter, baring duduk (sit-up), lompat jauh tanpa awalan, lari 1000 meter dan kelentukan. Hasil pengukuran kesegaran jasmani sebelum perlakuan terdapat 14 subjek memiliki kategori kesegaran jasmani baik sekali (>431 poin) dan sembilan subjek dengan kategori kesegaran jasmani baik (376-430 poin). Terdapat peningkatan rerata skor kesegaran jasmani setelah perlakuan dengan 19 subjek memiliki kategori kesegaran jasmani baik sekali dan empat subjek dengan kategori kesegaran jasmani baik.

\section{Tabel 2. Nilai Kesegaran Jasmani dan Komponen Sebelum dan Setelah Perlakuan}

\begin{tabular}{llccl}
\hline \multirow{2}{*}{ Kesegaran Jasmani } & \multirow{2}{*}{ Jenis Pengukuran } & \multicolumn{2}{c}{ Rerata } & \multirow{2}{*}{$\boldsymbol{p}$} \\
\cline { 3 - 4 } & & Sebelum & Sesudah & $0,005^{*}$ \\
Nilai Total Kesegaran Jasmani & & $442,52 \pm 30,01$ & $449,57 \pm 25,58$ & $0,029^{*}$ \\
Kecepatan (s) & Lari 50 meter & $7,07 \pm 0,36$ & $6,94 \pm 0,35$ & 0,056 \\
Daya ledak otot (cm) & Lompat jauh tanpa awalan & $225,30 \pm 16,25$ & $222,09 \pm 17,43$ & $0,037^{*}$ \\
Daya tahan kardiorespirasi (s) & Lari 1000 meter & $255 \pm 22,50$ & $250 \pm 22,45$ & $0,033^{2}$ \\
\hline
\end{tabular}

*Paired $t$-test, memiliki perbedaan yang bermakna $(p<0,05)$

Pada penelitian ini terdapat tiga komponen kesegaran jasmani menggunakan metode ACSPFT yang diamati perubahannya sebagai akibat adanya penerapan carbohydrate loading modifikasi. Ketiga komponen tersebut adalah kecepatan, daya ledak otot dan daya tahan kardiorespirasi. Perbaikan nilai total kesegaran jasmani, tidak lantas diikuti peningkatan hasil ukur pada tiap komponen tes kesegaran jasmani menggunakan metode ACSPFT. Terdapat perbaikan pada hasil pengukuran komponen kecepatan dan daya 
tahan kardiorespirasi, rerata yang ada mengindikasikan perbedaan yang bermakna. Pada komponen daya ledak otot terjadi penurunan rerata ukur menjadi 222,09 \pm $17,43 \mathrm{~cm}$. Terdapat 16 subjek dengan hasil lompatan lebih pendek dari pada sebelum perlakuan. Lima subjek berhasil memperbaiki hasil lompatan terdahulu dan dua subjek dengan hasil lompatan tetap.

\section{Perubahan Indikator Status Gizi Sebelum dan Setelah Perlakuan}

Tabel 3. Perbedaan Hasil Ukur Variabel Sebelum dan Setelah Perlakuan

\begin{tabular}{|c|c|c|c|}
\hline \multirow{2}{*}{ Jenis Pengukuran } & \multicolumn{2}{|c|}{ Rerata } & \multirow{2}{*}{$p^{*}$} \\
\hline & Sebelum & Sesudah & \\
\hline Indeks Massa Tubuh (IMT) $\left(\mathrm{kg} / \mathrm{m}^{2}\right)$ & $20,57 \pm 1,77$ & $20,77 \pm 1,79$ & 0,000 \\
\hline Persen lemak $(\%)$ & $11,64 \pm 2,71$ & $11,96 \pm 2,56$ & 0,001 \\
\hline Massa Tubuh Tanpa Lemak (kg) & $50,41 \pm 5,71$ & $50,76 \pm 5,82$ & 0,003 \\
\hline Kadar Glukosa Darah (mg/dl) & $78,91 \pm 15,20$ & $87,48 \pm 11,96$ & 0,037 \\
\hline
\end{tabular}

*Paired $t$-test, memiliki perbedaan yang bermakna $(p<0,05)$

Mayoritas subjek mengalami kenaikan berat badan selama perlakuan. Kenaikan berat badan terendah sebesar 200 gram dan tertinggi sebesar 1500 gram. Hal ini berdampak peningkatan rerata indeks massa tubuh (IMT) mencapai 20,77 $\pm 1,79 \mathrm{~kg} / \mathrm{m}^{2}$ dengan kategori status gizi normal. Terdapat kenaikan persen lemak tubuh pada 15 subjek, rerata sebelum perlakuan sebesar $11,64 \pm 2,71 \%$ dan setelah perlakuan sebesar $11,96 \pm 2,56 \%$. Terdapat satu subjek dengan persentase persen lemak dibawah normal (8-18\%) yaitu dengan nilai $7,1 \%$. Terjadi peningkatan massa tubuh tanpa lemak subjek yaitu berkisar antara 170-1400 gram.

Pengukuran glukosa darah yang dilakukan setelah melakukan aktivitas fisik (tes kesegaran jasmani) ditujukan untuk melihat perbedaan penurunan glukosa darah akibat aktivitas olahraga. Terdapat perbedaan yang bermakna dari hasil pengukuran kadar glukosa darah antara sebelum dan setelah perlakuan dengan $\mathrm{p}=0,037$.

Variabel paling berpengaruh terhadap kesegaran jasmani atlet sepak bola

Tabel 4. Variabel paling berpengaruh terhadap kesegaran jasmani

\begin{tabular}{lcc}
\hline Variabel Independen & $\mathbf{t}$ & $\boldsymbol{p}^{*}$ \\
\hline Indeks massa tubuh & 0,070 & 0,945 \\
Persen lemak & $-3,166$ & 0,005 \\
Massa tubuh tanpa lemak & 2,405 & 0,027 \\
Asupan karbohidrat & 1,248 & 0,228 \\
\hline Variabel dependen : kesegaran jasmani setelah perlakuan
\end{tabular}

Analisa multivariat digunakan untuk mengetahui variabel yang paling berpengaruh terhadap kesegaran jasmani pada atlet sepak bola yaitu indeks massa tubuh, persen lemak, massa tubuh tanpa lemak dan asupan karbohidrat. Didapatkan nilai $R^{2}$ ( $R$ Square) menunjukkan $62,1 \%$ dari varian kesegaran jasmani dapat dijelaskan oleh perubahan dalam variabel indeks massa tubuh, persen lemak, massa tubuh tanpa lemak dan asupan karbohidrat. Nilai uji statistik DurbinWatson $=1,728$, jadi dapat diasumsikan tidak terjadi autocorrelation. Tabel anova mengindikasikan bahwa regresi berganda secara statistik sangat signifikan dengan $\mathrm{p}=0,001$. Persen lemak dan massa tubuh tanpa lemak menjadi variabel yang paling berpengaruh terhadap kesegaran jasmani masing-masing dengan $\mathrm{p}<0,05$. Persamaan regresi berganda yang diperoleh dengan menggunakan metode kuadrat terkecil kriteria (least squares criterion) adalah $\mathrm{Y}=157,662-13,716 \mathrm{X} 1$ $+3,410 \mathrm{X} 2$, dimana: $\mathrm{Y}=$ kesegaran jasmani, $\mathrm{X} 1=$ persen lemak dan X2=massa tubuh tanpa lemak.

\section{PEMBAHASAN}

\section{Karakteristik Subjek}

Penelitian ini menggunakan subjek sebanyak 23 orang yang tergabung dalam satu kelompok perlakuan. Subjek merupakan atlet sepak bola di Diklat Bintang Pelajar Kabupaten Semarang. Keseluruhan subjek merupakan siswa Sekolah Menengah Atas (SMA) yang berada di kelas X, XI, dan XII.

Rerata usia subjek yaitu $16,24 \pm 1,03$ tahun dengan subjek termuda berusia 14,6 tahun dan tertua berusia 18,5 tahun. Daya tahan kardiovaskuler akan terus meningkat hingga usia 20 tahun, mencapai maksimal pada usia 20-30 tahun. Dilaporkan bahwa penurunan kelenturan dimulai sekitar usia 10 tahun pada anak laki-laki dan 12 tahun pada anak perempuan dan bukti menunjukkan bahwa dewasa yang lebih tua mempunyai kelenturan kurang dibanding dewasa muda. ${ }^{32}$ Hal ini disebabkan oleh penurunan fungsi organ transpor dan penggunaan oksigen yang terjadi 
akibat bertambahnya usia. Penurunan secara drastis dapat berkurang bila tetap melakukan olahraga aerobik. ${ }^{\mathbf{6} 12}$ Efek usia terhadap kebugaran aerobik yaitu penurunan sekitar 8 hingga $10 \%$ per dekade untuk individu yang tidak aktif dan berkisar $4-5 \%$ per dekade yaitu jika seseorang melakukan latihan rutin bersifat fitness. ${ }^{12}$

Salah satu yang mempengaruhi kesegaran jasmani adalah kapasitas pembawa oksigen. Zat besi sebagai komponen yang penting pada hemoglobin berperan sebagai pigmen sel darah merah pembawa oksigen. ${ }^{13,15}$ Terdapat hubungan yang erat antara laju konsumsi oksigen miokardium dengan kerja yang dihasilkan oleh jantung. Makin kuat jantung bekerja maka akan semakin banyak oksigen yang dibutuhkan oleh sel-sel jantung. ${ }^{21}$ Terdapat hubungan kadar hemoglobin dengan ketahanan fisik atlet sepak bola PSIS Semarang. ${ }^{34}$ Keseluruhan subjek mempunyai kadar hemoglobin normal yaitu berada di atas $13 \mathrm{~g} / \mathrm{dl}$ dengan rerata 14,49 $\pm 0,61 \mathrm{~g} / \mathrm{dl}$. Kadar hemoglobin seorang atlet laki-laki yang berada di bawah $13 \mathrm{~g} / \mathrm{dl}$ mengindikasikan sport anemia, merupakan keadaan terjadinya kerusakan sel-sel darah merah sebagai akibat latihan berat yang pada umumnya menyebabkan kehilangan zat besi sehingga kadar hemoglobin menurun hingga $<13 \mathrm{~g} / \mathrm{dl}$ pada laki-laki. Faktor-faktor penyebab terjadinya sport anemia antara lain, ekskresi berlebih melalui keringat atau menstruasi pada wanita, peningkatan kebutuhan zat besi karena terjadinya kerusakan sel-sel darah merah, defisiensi zat-zat besi pembentuk darah seperti protein, vitamin $B_{12}$, asam folat dan zat besi, reaksi faali akibat latihan fisik yang berat sehingga menimbulkan hemodilusi dan berakibat pada pseudoanemia. $^{2}$

Pada penelitian ini rerata indeks massa tubuh (IMT) subjek setelah perlakuan sebesar 20,57 \pm 1,77 $\mathrm{kg} / \mathrm{m}^{2}$. IMT merupakan cara termudah untuk memperkirakan obesitas serta berkorelasi tinggi dengan persen lemak tubuh, sederhana dan bisa digunakan dalam penelitian populasi berskala besar. Berdasarkan kurva IMT dari CDC (The Centers for Disease Control) didapatkan seluruh subjek dalam penelitian ini berstatus gizi normal. Mewujudkan prestasi yang optimal, pemain sepak bola harus mempunyai bentuk tubuh yang ideal yaitu sehat, kuat, tinggi dan tangkas serta mempunyai indeks massa tubuh (IMT) normal. $^{\mathbf{1 4}}$ Terdapat hubungan positif antara nilai $\mathrm{VO}_{2}$ max dengan status gizi, baik dalam kondisi gizi normal maupun malnutrisi. ${ }^{35}$ Penelitian pada atlet di Training center Jakarta terlihat bahwa semakin tinggi indeks massa tubuh maka akan semakin rendah $\mathrm{VO}_{2}$ max. ${ }^{32}$

Komposisi tubuh merupakan jumlah seluruh bagian tubuh yang terdiri dari adipose atau jaringan lemak dan massa jaringan bebas lemak. Massa tubuh tanpa lemak (lean body mass) adalah semua sel selain lemak seperti tulang, otot dan air. ${ }^{18}$ Indikator komposisi tubuh dipergunakan di klinik untuk mengidentifikasi kekurangan gizi, serta memantau perubahan komposisi tubuh selama pemberian dukungan gizi. ${ }^{18}$ Komposisi atau struktur tubuh yang menguntungkan berpengaruh terhadap ketahanan fisik yang prima dan merupakan salah satu syarat yang harus dipenuhi untuk dapat meraih prestasi. Komposisi tubuh didefinisikan sebagai keadaan tubuh dengan massa otot yang mampu menyimpan cadangan glikogen seoptimal mungkin. Keadaan demikian dapat dicapai melalui latihan yang intensif (cukup lama, frekuensi, dan intensitas latihan) dengan disertai pengaturan konsumsi zat gizi (asupan yang tepat guna baik jenis, jumlah dan waktu). ${ }^{32}$ Pengukuran komposisi tubuh subjek yaitu persen lemak didapatkan rerata sebesar 11,64 $\pm 2,71 \%$ sementara nilai massa tubuh tanpa lemak subjek didapatkan dengan cara perhitungan yaitu selisih antara berat badan aktual dengan persen lemak $(\mathrm{kg})$. Massa tubuh tanpa lemak terdiri dari semua sel selain lemak seperti tulang, otot dan air. Ukuran tubuh atlet sangat mendapat perhatian, pada umumnya dengan patokan ideal berat badan dengan tinggi badan digunakan untuk mengetahui keidealan ukuran tubuh seorang atlet. Cara tersebut tidak dapat diterapkan pada semua atlet karena tiap semua cabang olahraga memiliki patokan ukuran tubuh yang ideal. ${ }^{35}$ Patokan ukuran tubuh pada atlet biasanya berdasarkan presentase lemak. Sebagai contoh terdapat hubungan positif antara persentase lemak tubuh dengan ketahanan fisik atlet sepak bola. ${ }^{36}$ Atlet sepak bola harus proporsional antara massa otot dan lemak. Presentase lemak yang ideal adalah bekisar 8-18\% pada atlet sepak bola pria hal ini jauh berbeda jika dibandingkan dengan persentase lemak ideal seorang pesenam pria yaitu $4-6 \% .14,35$

Hasil recall asupan makanan yang dilakukan sebelum intervensi didapatkan rerata energi yang dikonsumsi subjek dalam sehari sebesar $2798 \pm 254$ kalori. Terdapat ketimpangan antara asupan yang dikonsumsi dengan kebutuhan yang diperlukan oleh subjek. Tiga subjek mempunyai kategori asupan defisit $(<70 \%)$, lima belas subjek mempunyai kategori asupan kurang (70-80\%) dan lima subjek dengan kategori asupan sedang (80-99\%) dari kebutuhan energi yang seharusnya dikonsumsi. Kebutuhan energi dihitung dengan mempertimbangkan kebutuhan energi basal, specific dynamic action (SDA), aktivitas fisik dan penambahan kalori untuk pertumbuhan sebesar $10 \%$. Selain latihan rutin sepak bola yang diselenggarakan sebanyak 11 kali dalam satu minggu. Pencapaian konsumsi karbohidrat terhadap kebutuhan kalori yang diperlukan sebesar 50,50\%. Disarankan konsumsi karbohidrat 7-10 gr/kg berat badan/hari untuk latihan berat. Paling tidak $60 \%$ dari total energi sehari berasal dari karbohidrat. Hal ini akan membantu mencegah habisnya simpanan glukosa. Atlet dengan $65 \mathrm{~kg}$ 
menggunakan $8800 \mathrm{kj}$ dalam latihan. Dibutuhkan 4200-7500 kj atau 250-450 gram karbohidrat sehingga kebutuhan normal sehari untuk karbohidrat 300-350 gram. Atlet akan mengkonsumsi karbohidrat 550-800 gram.hari atai $8,5-12,3 \mathrm{gram} / \mathrm{kg}$ berat badan/hari. Ketika cadangan karbohidrat rendah atlet akan berusaha lebih banyak mengkonsumsi lemak dan protein. Diet karbohidart untuk atlet olahraga berat sekitar 7-10 gram $/ \mathrm{kg}$ berat badan/hari. Diperkirakan menghasilkan 1-2 gram glukosa/kg berat badan. Pemulihan dari glikogen terjadi secara cepat setelah olahraga. ${ }^{37}$ Asupan gizi menjadi unsur yang cukup penting dalam pembinaan sepak bola usia muda, selain berguna untuk mengoptimalkan pertumbuhan juga ditujukan untuk menyiapkan kondisi terbaik atlet baik sebelum, saat dan setelah pertandingan berlangsung. Faktor gizi menjadi bagian science support dalam rangka mewujudkan prestasi sepak bola. ${ }^{29}$

\section{Penerapan Carbohydrate Loading Modifikasi}

Penerapan carbohydrate loading modifikasi dilakukan selama satu minggu. Cara modifikasi dipilih karena beberapa keuntungan seperti ketiadaan pemberian latihan dengan intensitas berat serta pembatasan asupan karbohidrat pada awal perlakuan yang dikhawatirkan akan berdampak negatif yaitu terjadinya penurunan berat badan secara drastis dan ketosis. ${ }^{1,10}$

Hasil recall 24 jam dan commstock total asupan energi subjek didapatkan rerata sebesar $3912 \pm$ 133 kalori. Total asupan energi mencukupi kebutuhan yang seharusnya dikonsumsi atlet dengan 20 subjek mempunyai kategori asupan baik (>100\%) dan dua orang subjek dengan kategori asupan sedang (80$90 \%){ }^{18}$ Pemenuhan asupan energi perlakuan diwujudkan dengan pemberian tiga kali makanan besar dan tiga kali snack. Rerata asupan karbohidrat meningkat setelah intervensi yaitu mencapai $648,58 \pm$ 38,42 gram dengan persentase pemenuhan dari total kalori yang diperlukan sebesar $69,48 \%$ dengan 22 subjek mempunyai kategori asupan karbohidrat lebih (>100\% angka kecukupan) dan satu orang subjek dengan kategori baik (80-100\% angka kecukupan). ${ }^{33}$ Rerata asupan karbohidrat mempunyai perbedaan yang bermakna $(p<0,05)$.

Terdapat kenaikan rerata berat badan pada subjek yaitu $57,20 \pm 7,38 \mathrm{~kg}$ pada sebelum perlakuan dan $57,79 \pm 7,49 \mathrm{~kg}$ setelah perlakuan. Kenaikan berat badan ini tentunya berdampak pada peningkatan ratarata indeks massa tubuh subjek. Kenaikan berat badan yang bervariasi pada subjek berkaitan dengan perbedaan intensitas latihan yang diterima oleh subjek, (posisi bermain sebagai pemain tengah atau gelandang) dan kecepatan metabolisme tubuh pada tiap subjek. ${ }^{1,2,6}$

Indikator status gizi yang turut serta diamati dalam penelitian ini adalah komposisi tubuh yaitu persen lemak dan massa tubuh tanpa lemak. Atlet sepak bola harus proporsional antara massa otot dan lemak. Presentase lemak yang ideal adalah bekisar $8-18 \% .^{32,35}$ Terjadi peningkatan rerata persen lemak tubuh sebesar $11,96 \pm 2,56 \%$ dan menghasilkan perbedaan yang bermakna $(\mathrm{p}=0,007)$. Diharapakan dengan penerapan carbohydrate loading dapat menurunkan persen lemak tubuh. Peningkatan persen lemak tubuh dimungkinkan terjadi karena glukosa akibat pemberian asupan tinggi karbohidrat yang tidak segera dibutuhkan untuk energi, glukosa ekstra yang masuk secara kontinyu ke dalam sel disimpan sebagai glikogen atau diubah menjadi lemak. ${ }^{15}$ Glukosa terutama disimpan sebagai glikogen sampai sel telah menyimpan glikogen sebanyak kemampuannya (jumlah yang cukup untuk mensuplai kebutuhan energi tubuh hanya selama 12 sampai 24 jam. ${ }^{15}$ Bila sel (terutama sel hati dan otot) mendekati saturasi glikogen, glukosa tambahan diubah menjadi lemak dalam sel hati dan sel lemak serta disimpan dalam sel lemak. Trigliserida merupakan bentuk deposit lemak pada manusia yang disimpan dalam jaringan adeposit yang tersebar dalam tubuh. ${ }^{31}$ Trigliserida tersebut disimpan sebagai lemak intermuskular dan intramuskular, lemak yang terdapat di sekitar organ pencernaan dan lemak subkutan. Terdapat sekitar 50\% dari persen lemak total tubuh berada pada jaringan subkutan. ${ }^{31}$

Pengukuran glukosa darah sewaktu ditujukan untuk melihat tingkat penurunan glukosa darah subjek setelah melakukan aktivitas fisik. Salah satu akibat dari suatu aktivitas fisik atau olahraga adalah penurunan glukosa darah adapun besarnya penurunan tergantung pada intensitas dan lama aktivitas. ${ }^{20}$ Pada beberapa kondisi penurunan glukosa darah dapat mencapai hingga pada tahap hipoglikemia, hal tersebut merepresentasikan simpanan glukosa dan glikogen yang makin berkurang. ${ }^{20}$ Terdapat perbaikan pada hasil pengukuran glukosa darah. Rerata kadar glukosa darah setelah penerapan carbohydrate loading modifikasi yaitu $87,48 \pm 11,96 \mathrm{mg} / \mathrm{dl}$. Hasil yang ada mengalami peningkatan jika dibandingkan dengan rerata kadar glukosa darah sebelum intervensi yakni sebesar $78,91 \pm 15,20 \mathrm{mg} / \mathrm{dl}$ dan menghasilkan perbedaan yang bermakna dengan $\mathrm{p}=0,037$, dari hasil yang ada 19 subjek mengalami perbaikan kadar glukosa darah, tiga subjek mengalami penurunan dan satu subjek dengan hasil tetap. Penurunan glukosa darah setelah melakukan aktivitas olahraga dimungkinkan karena terjadinya peningkatan sensitivitas insulin dan rendahnya jumlah produksi atau pemecahan glukosa. ${ }^{15,19,21}$ Insulin menghambat fosforilase hati, yang merupakan enzim utama yang menyebabkan terpecahnya glikogen dalam hati menjadi glukosa. Keadaan ini mencegah pemecahan glikogen yang sudah tersedia dalam sel-sel hati. Kadar glukosa darah juga dikaitkan dengan hormon glukagon, merupakan 
hormon yang disekresikan oleh sel-sel alfa pulau Langerhans sewaktu kadar glukosa darah turun, mempunyai fungsi yang bertentangan dengan efek insulin. Efek utama glukagon terhadap metabolisme glukosa adalah membantu pemecahan glikogen hati (glikogenolisis) dan meningkatkan proses glukoneogenesis di dalam hati, selain itu glukagon juga berperan meningkatkan glikogenolisis di dalam hati. Efek glukagon tersebut berguna dalam meningkatkan glukosa darah. ${ }^{15,21}$

\section{Kesegaran Jasmani Atlet Sepak Bola}

Kesegaran jasmani merupakan suatu keadaan yang dimiliki atau dicapai seseorang dalam kaitannya dengan kemampuan untuk melakukan aktivitas fisik. Istilah kesegaran jasmani juga meliputi kemampuan untuk melakukan kegiatan atau pekerjaan sehari-hari dan adaptasi terhadap pembebanan fisik tanpa menimbulkan kelelahan yang berarti. ${ }^{6,28}$

Hasil tes kesegaran jasmani dengan menggunakan tes ACSPFT setelah penerapan perlakuan didapatkan rerata $449,57 \pm 25,58$ poin. Terdapat perbedaan hasil dibandingkan dengan pengukuran tes kesegaran jasmani sebelum perlakuan dengan $\mathrm{p}=0,005$. Sebanyak $82 \%$ subjek mempunyai kategori kesegaran jasmani baik sekali, dan sisanya $18 \%$ atau empat orang subjek mempunyai kategori kesegaran jasmani baik Hasil akhir pengukuran tes kesegaran jasmani sangat dipengaruhi oleh motivasi subjek. Hal ini tampak pada komponen tes kekuatan statis (bergantung angkat badan), daya ledak otot (lompat jauh tanpa awalan), dan kelentukan (lentu togok) didapatkan penurunan hasil ukur pada sebagian besar subjek. Hasil pengukuran pada komponen yang memiliki skala hitung (waktu) didapatkan perbedaan rerata yang bernilai positif dan bermakna. Pada penelitian ini juga diamati pengaruh penerapan carbohydrate loading modifikasi terhadap beberapa komponen kesegaran jasmani yaitu kecepatan, daya ledak otot, daya tahan kardiorespirasi. Pengukuran pada komponen kecepatan dengan tes lari 50 meter (jangka pendek) di dapatkan hasil dengan $\mathrm{p}=0,029$, dan pengukuran komponen daya tahan kardiorespirasi terdapat perbaikan bermakna dengan $\mathrm{p}=0,037$. Hasil yang didapatkan sejalan dengan penelitian oleh Sherman yaitu terdapat peningkatan asupan karbohidrat selama latihan pada pelari dapat meningkatkan waktu tempuh sebesar 26\%. Hasil pengukuran komponen daya ledak otot dengan tes lompat jauh tanpa awalan di dapatkan perbedaan yang kurang bermakna $(p=0,056)$. Penurunan hasil ukur subjek pada beberapa komponen kesegaran jasmani dimungkinkan terjadi karena peningkatan berat badan yang berdampak pada perasaan berat dan kekakuan otot yang dapat mengakibatkan otot menegang serta keletihan. ${ }^{1,10}$ Wawancara yang dilakukan kepada subjek didapatkan hasil bahwa mayoritas subjek merasakan penambahan berat badan dan kekakuan dibagian kaki.

Kelelahan otot merupakan suatu kondisi yang dihasilkan dari kontraksi otot yang kuat dan berkepanjangan. ${ }^{22}$ Kelelahan otot dalam latihan jangka pendek yang maksimal berhubungan dengan penurunan oksigen dan kenaikan asam laktat darah dan otot. ${ }^{21,23}$ Meningkatnya kadar asam laktat tersebut akan mengganggu keseimbangan cairan dan elektrolit dalam tubuh, sehingga menyebabkan menurunnya kekuatan dan kecepatan kontraksi atau gerakan otot. ${ }^{21}$

Sumber energi utama untuk lari cepat (50 dan 100 meter) adalah keratin fosfat (4-5 detik pertama) dan kemudian glikolisis anaerob, dengan menggunakan glikogen otot sebagai sumber glukosa. Dua tempat utama kontrol metabolik adalah glikogen di glikogen fosforilase dan di PFK-1. Glikogen fosforilase diaktifkan oleh $\mathrm{Ca}^{2+}$ (dibebaskan dari reticulum sarkoplasma sewaktu kontraksi), epinefrin dan AMP. PFK-1 diaktifkan oleh AMP, $\mathrm{P}_{1}$ dan $\mathrm{NH}_{3}$. Pembuktian terhadap efisiensi proses-proses ini adalah aliran melalui glikolisis dapat meningkat hingga 1000 kali lipat sewaktu lari cepat. ${ }^{15}$ Besarnya sumbangan proses anaerobik dan aerobik pada lari cepat 100 meter yaitu $95: 5 \% .{ }^{2}$ Pada lari dengan jarak tempuh yang lebih jauh yaitu 1000 meter atau lebih. Sumber bahan bakar utama adalah glukosa darah dan asam lemak bebas, yang terutama berasal dari penguraian trigliserol di jaringan adipose yang dirangsang oleh epinefrin. Glikogen hati diuraikan untuk mempertahankan kadar glukosa darah. Glikogen otot juga merupakan sumber bahan bakar, tetapi senyawa ini diuraikan jauh lebih lembat dari pada sewaktu lari cepat. Besarnya sumbangan proses anaerobik dan aerobi pada lari cepat 1000 meter yaitu $50: 50 \% .^{2}$ Kontraksi otot yang kuat dan lama dapat menyebabkan kelelahan otot. Kelelahan otot pada atlet berbading lurus dengan penurunan kretinin fosfat, glikogen dan ATP otot. Sedikitnya jumlah zat-zat tersebut menghasilkan mekanisme kontraksi tidak dapat menghasilkan energi. ${ }^{24}$

Sistem ATP-PC merupakan produksi ATP yang cepat melalui pemecahan PC. Phospocreatin $(P C)$ merupakan senyawa yang mengandung fosfat dan tertimbun di otot. Sistem glikolisis laktasid merupakan produksi ATP dari rangkaian glikolisis anaerobik yang menghasilkan asam laktat. Sedangkan sistem aerobik merupakan produksi ATP dari sumber energi glukosa/glikogen dan asam lemak dengan bantuan oksigen. Dengan demikian, sumber energi yang dominan digunakan untuk memproduksi ATP adalah glikogen/glukosa dan asam lemak. Rendahnya cadangan glikogen otot akan mengurangi kemampuan otot untuk memproduksi ATP melalui glikolisis sehingga mengganggu kontraksi otot. Cadangan glikogen otot kurang dari $20 \mathrm{mmol} / \mathrm{kgBB}$ yang akan 
mengganggu kontraksi otot. Kemudian rendahnya mobilisasi asam lemak juga akan mengganggu pembentukan ATP secara aerobik. Produksi ATP secara aerobik melibatkan bantuan oksigen. Suplai oksigen tergantung dari $\mathrm{VO}_{2} \mathrm{Max}$ yang melibatkan peran ventilasi, kardiovaskular dan respirasi otot. ${ }^{25}$ Bila suplai oksigen tidak terpenuhi akan mengakibatkan produksi ATP secara anaerobik (sistem glikolisis laktik) yang berdampak pada penumpukan asam laktat. ${ }^{28}$ Menurunnya kemampuan otot akibat akumulasi asam laktat disebabkan berkurangnya kecepatan laju removal asam laktat, yang disebabkan adanya ketidak seimbangan antara produksi asam laktat dengan removal asam laktat di hati. ${ }^{15,21,25}$ Kelelahan karena gangguan perambatan impuls, mekanik kontraksi otot dan suplai energi akan menyebabkan kelelahan perifer. ${ }^{15,25}$

Pada saat dehidrasi akan terjadi peningkatan suhu otot yang disebabkan berkurangnya perfusi darah dalam jaringan selama kontraksi dan relaksasi otot. ${ }^{30}$ Peningkatan suhu yang terjadi akan mengganggu rangkaian kimia dalam metabolisme glikolisis sehingga akan menghambat produksi ATP. Kontraksi otot akan terganggu bila terdapat penurunan produksi ATP. Produksi ATP tersebut ditentukan oleh faktor suplai sumber energi dan oksigen. Sumber energi yang digunakan saat terjadi dehidrasi adalah glikogen. ${ }^{30}$ terjadi peningkatan degradasi glikogen otot saat terjadi dehidrasi. Produksi ATP melalui rangkaian glikolisis aerobik memerlukan suplay oksigen yang memadai. Kebutuhan oksigen otot tersebut dipengaruhi oleh $V_{2}$ Max yang melibatkan sistem jantung, paru dan pembuluh darah untuk berfungsi secara optimal dalam mengambil oksigen dan menyalurkannya ke jaringan yang aktif sehingga dapat digunakan pada proses metabolisme di otot.

Pembentukan titik-titik percabangan di glikogen berlangsung lebih lambat dari pada penambahan unit-unit glukosa ke suatu rantai linier. Dengan melakukan latihan carbohydrate loading (saat glikogen otot terkuras) dan diikuti dengan menyantap makanan tinggi karbohidrat sehingga terjadi sintesis glikogen cepat dengan percabangan yang lebih sedikit daripada normal. ${ }^{15}$ Penerapan carbohydrate loading modifikasi memungkinkan peningkatan simpanan glikogen hingga tiga kali lipat dari biasanya yaitu sebesar 130-205 $\mathrm{mmol} / \mathrm{kg} \mathrm{BB}$, sehingga dapat dipergunakan untuk aktivitas berat yang memerlukan waktu lama. Pada penelitian ini, adanya perubahan simpanan glikogen selama perlakuan diamati melalui peningkatan massa tubuh tanpa lemak dan kadar glukosa darah setelah melakukan aktivitas fisik. Penerapan carbohydrate loading modifikasi memungkinkan status hidrasi dapat dipertahankan sebab pada pemakaian 1 gram glikogen selalu disertai pembebasan air sebanyak 2,7 gram. Apabila glikogen mengalami metabolisme aerobik, akan terbentuk 0,6 gram air, sehingga pada pembebasan 1 gram glikogen akan diperoleh air sejumlah kurang lebih 3 gram. Hal ini cukup untuk menggantikan cairan yang hilang. Hasil penelitian ini sejalan dengan penelitian pada atlet sepak bola Brazil yang menyimpulkan bahwa pemberian carbohydrate loading dapat meningkatkan kondisi fisik dan fisiologis setelah 16 jam pertandingan sepak bola. ${ }^{26}$

Persen lemak dan massa tubuh tanpa lemak menjadi variabel yang paling berpengaruh terhadap kesegaran dengan nilai $p=0,005$ dan $p=0,027$. Hal ini berbeda dengan hasil penelitian pada sekolah sepak bola (SSB) Undip Semarang yang menyimpulkan bahwa tidak terdapat hubungan antara persen lemak tubuh dengan kesegaran jasmani atlet sepak bola. ${ }^{35}$ Komposisi tubuh dan berat badan adalah dua dari banyak faktor yang memberi kontribusi terhadap optimal exercise performance. Berat badan dapat mempengaruhi speed, endurance, dan power seorang atlet, sementara komposisi tubuh dapat menghasilkan strength, agility dan penampilan seorang atlet. Seseorang dengan komposisi tubuh normal dengan otot atau rasio lemak lebih besar, seringkali menguntungkan dalam olahraga yang membutuhkan kecepatan (speed). Terbentuknya persen lemak (body fat mass) dengan perbandingan massa tubuh tanpa lemak (lean body mass) berkenaan dengan performa atlet. Hasil penelitian membuktikan bahwa jumlah persen lemak yang tepat akan menambah kekuatan, tenaga dan kecerdasan. Upaya mewujudkan persen lemak dan massa tubuh tanpa lemak yang ideal ditempuh dengan latihan (exercise) juga memperhatikan asupan gizi baik jumlah maupun waktu pemberian. ${ }^{32}$ Tidak terdapat pengaruh antara indeks massa tubuh dengan kesegaran jasmani, $\mathrm{p}=0,945$. Hal ini sesuai dengan hasil penelitian Agustini yang menyimpulkan tidak adanya hubungan antara indeks massa tubuh dengan kesegaran jasmani. ${ }^{38}$

Kelemahan dalam penelitian ini adalah pengukuran variabel intensitas latihan dan aktivitas fisik yang mempengaruhi tingkat kesegaran jasmani belum dapat diselenggarakan dengan pengukuran yang teliti. Hal ini disebabkan alat untuk menilai latihan dan aktivitas fisik berupa kuesioner yang berdasarkan kegiatan/aktivitas mingguan subjek dan tidak bisa mengukur secara rinci aktivitas lain yang sering dilakukan subjek misalnya aktivitas sedentari subjek di sekolah dan asrama serta perbedaan beban latihan yang diterima oleh subjek berdasarkan posisi bermain sepak bola. Seharusnya dinilai menggunakan alat ukur aktivitas fisik seperti akselometer. Indikator yang mencerminkan keberhasilan penerapan carbohydrate loading adalah peningkatan kadar glikogen, namun pada penelitian ini pengukuran glikogen tidak bisa diselenggarakan. Pengukuran kadar glukosa darah 
setelah melakukan tes kesegaran jasmani perlu ditunjang dengan data pengukuran lain seperti kadar asam laktat untuk lebih merepresentasikan tingkat kelelahan pada atlet.

\section{SIMPULAN}

Terdapat peningkatan rerata kesegaran jasmani subjek setelah mendapat perlakuan. Terdapat perbedaan yang bermakna pada pengukuran komponen kesegaran jasmani yaitu kecepatan dan daya tahan kardiorespirasi namun tidak terdapat perbedaan bermakna pada hasil ukur komponen daya ledak otot sebelum dan setelah perlakuan. Terdapat peningkatan hasil ukur indikator status gizi (indeks massa tubuh, persen lemak dan massa tubuh tanpa lemak) setelah perlakuan. Terdapat perbaikan pada hasil ukur kadar glukosa darah setelah melakukan aktivitas fisik (tes kesegaran jasmani). Persen lemak dan massa tubuh tanpa lemak menjadi variabel yang paling berpengaruh terhadap kesegaran jasmani subjek.

\section{SARAN}

1. Prinsip pengelolaan asupan makanan dan latihan dengan metode carbohydrate loading modifikasi dapat diterapkan dalam penyelenggaraan program pemusatan latihan maupun perorangan dengan tujuan untuk meningkatkan simpanan glikogen dalam tubuh.

2. Penerapan carbohydrate loading modifikasi dilaksanakan mendekati pelaksanaan pertandingan dengan memperhatikan karakteristik cabang olahraga baik berupa jenis olahraga (endurance, strength, power), sistem penggunaan energi dan prasyarat khusus lain seperti adanya penggolangan berat badan.

3. Diperlukan penelitian lebih lanjut dengan instrumen yang lebih tepat untuk menilai pengaruh pemberian asupan tinggi karbohidrat terhadap kesegaran jasmani dan tingkat kelelahan atlet sepak bola.

4. Diperlukan penelitian lebih lanjut mengenai pemberian asupan tinggi karbohidrat dengan mempertimbangkan indeks glikemik bahan makanan.

\section{DAFTAR PUSTAKA}

1. Fink H.H, Burgon L.A, Mikesky A.E. Practical applications in sport nutrition. Boston : Jones and Bartlett Publishers; 2006. p.430-1

2. Irianto Djoko P. Panduan gizi lengkap keluarga dan olahragawan. Yogyakarta: Penerbit Andi; 2007. P.43-8
3. Aryanti Tjaronosari,Hidayat Nur. Pengaruh asupan karbohidrat pada periode latihan terhadap kebugaran atlet sepak bola di klub PSS Yogyakarta. Nutrisia. Vol 5 No.2;2004

4. Fajar I, Tapriadi dan I. N. Tami. Pola konsumsi, status gizi dan kesegaran jasmani siswa sekolah sepak bola di Malang (skripsi). Edisi 29. Jakarta: Binadiknakes; 1998

5. Ali Rosidi. Hubungan status gizi, status kesehatan dan aktivitas fisik dengan kesegaran jasmani atlet PSIS Semarang (Tesis). Institut Pertanian Bogor; 2000.

6. Depkes R.I.Pedoman Pengukuran Kesegaran Jasmani.Jakarta:Depkes RI Dirjen Pembinaan Kesehatan Masyarakat Direktorat Bina Upaya Kesehatan Puskesmas;1994. p 23-30

7. Remory Muchtar. Olah Raga pilihan sepak bola. Departemen Pendidikan dan Kebudayaan Dirjen Pendidikan Tinggi Proyek Pembinaan tenaga Kependudukan;1992. p.37

8. Louise M Burke, Gregory R Collier, Peter G Davis, Peter A Fricker, Andrew J. Muscle glycogen storage after prolonged exercise: effect of the frequency of carbohydrate feedings. [online] 1996 [dikutip 5 Maret 2011] Available from:URL:http://www.ajcn.org/content/64/1/115. full.pdf

9. Maughan J. editor.Nutrition in sport.Oxfort.Blackwell Science.2000. p.85-96

10. Walirsky Ira. Nutrition in exercise and sport. $3^{\text {rd }}$ ed.CRC Press. USA; 1998. P.81-90

11. O'Connor Helen. Clinical sport nutrition. Competition nutrition issues : preparation and recovery. Sydney: Mc Graw Hill book Company; 1994. p.307-314

12. Tabitha Sri H.W. Pengaruh asrama atlet sepak bola terhadap Status Gizi (IMT dan Kadar Hb), aktivitas fisik dan kesegaran jasmani (tesis). Program Pasca Sarjana Universitas Diponegoro Semarang; 2004

13. Goran M. Measurement issues related to studies of childhood obesity: assesment of body composition, body fat distribution, physical activity, and food intake. Pediatrics; 1998

14. Depkes RI. Gizi Atlet sepak bola. Depkes RI Dirjen Kesehatan Masyarakat Direktorat Gizi Masyarakat; 2003.

15. Robert K. Muray, Daryl K. Granner. Victor W Rodwell. Biokimia Harper edisi 27. Penerbit Jakarta: Buku Kedokteran EGC; 2009.p.166-173, 582-604.

16. William M Sherman, J Andrew Doyle, David R Lamb and Richard $M$ Strauss. Dietary carbohydrate, muscle glycogen and exercise performance during $7 d$ of training. American Journal Clinical Nutrition [online] 1993 [dikutip 
pada 25 Maret 2011] Available from:URL:http://www.ajcn.org/content/57/1/27.f ull.pdf

17. Anwari Irawan.Metabolisme energi tubuh dan olahraga. Polton Sport Science \& Performance Lab.Volume 01.2007.p.4-7

18. Supariasa IGN, Bakri B. Fajar I. Penilaian status gizi. Jakarta : Penerbit Buku Kedokteran EGC; 2002.p.192-4

19. Brun JF, Dumortier M, Fedou C \& Mercier J. Exercise hypoglycemia in nondiabetic subjects. Diabetes Metab 27;2001 92-106.

20. Kuipers H, Fransen EJ \& Keizer HA. Preexercise ingestion of carbohydrate and transient hypoglycemia during exercise. [online] 1999 [dikutip 14 Agustus 2011] Available from:URL:https://www.thiemeconnect.de/ejournals/pdf/sportsmed/doi/10.1055/ s-2007-971122.pdf

21. Guyton AC, Hall JE. Buku Ajar Fisiologi Kedokteran edisi 11. Alih bahasa: Setiawan I, Tengadi KA, Santoso A. Jakarta : EGC; 2008. p. $1347-8$.

22. Cantor F. Excessive skeletal muscle recruitment during strenuous exercise.European journal of applied physiology and occupational physiology.2008 May;2(5):399-405

23. Kent-Braun JA. Central and peripheral contributions to muscle fatigue in humans during sustained maximal effort. European journal of applied physiology and occupational physiology. 1999 jun;80(1):57-63

24. H.J. Green. Mechanisms of muscle fatigue in intense exercise. Journal of sports Sciences. 1997 Jun;15(3):247-256.

25. Munir Ahmad. Physiological Models of fatigue During Exercise. ISN Bulletin Volume 1, No.2, 2008.p.12-4

26. Orbetelli R, Valquer W. Carbohydrate loading in soccer players after the game. Effect on mood, muscle and physical performance.Medicine \& Science in Sport \& Exercise, ACSM, vol 35, $\mathrm{n}^{\circ} 5$, (sippl.):1180,2003

27. Mas'ud I. Dasar-dasar fisiologi kardiovaskuler. Jakarta: Penerbit Buku Kedokteran EGC; 2002

28. Nieman David. Exercise testing and prescriptiona health related approach $7^{\text {th }}$. New York: Mc Grow Hill.2011:242-248

29. Reilly Thomas. The science of training soccer. London and New York: Routledge.2007.p.178179

30. Douglas, J.C., Lawrance, E.A. \& Scott, J.M. National Athletic Trainers Association Position Statement: Fluid Replacement for Athletes. Journal of Athletic Training [online] 2000. [dikutip 5 Agustus 2011]
Availablefrom:URL:http://fossociety.com/pdf/sp orts_medicine/JSMP\%20Fluid\%20Recommendat ions\%20final.pdf

31. Gibson RS. Antropometric asessment of body composition. In Principle of Nutrition Assessment $2^{\text {nd }}$ ed.New York: Oxford; 2005

32. Weatherwax Dawn. Komposisi tubuh dan efeknya pada spektrum performa olahraga. [online] NSCA Sport Nutrition. 2008 Sept/Okt;7.5: 6-7. Available from:URL:

http://www.olympic.or.id/files/documents/journal 17.5.pdf

33. Widajanti Laksmi. Survei Konsumsi Gizi. Semarang :Badan Penerbit UNDIP.2009.p.79-80

34. Eldya Kartika. Hubungan tingkat konsumsi gizi (energi,protein,zat besi) dan status gizi (IMT, kadar $\mathrm{Hb}$ ) terhadap ketahanan fisik pada atlet sepak bola di PSIS Semarang (skripsi). Fakultas Kesehatan Masyarakat Universitas Diponegoro; 2006.

35. Frank I. Katch. Introduction to Nutrition, Exercise and Health $4^{\text {rd }}$ ed.London: Lea \& Febiger;1992.p.240-4

36. Galeh. Hubungan persentase lemak tubuh dengan ketahanan fisik atlet sepak bola (Skripsi). Program Studi Ilmu Gizi Fakultas Kedokteran Universitas Diponegoro Semarang; 2008.

37. Burke L, Frail H. Carbohydrate needs for training. Mc Graw Hall Book Company.Sydney;1994.p.150-7

38. Agustini Utari.Hubungan indeks massa tubuh dengan tingkat kesegaran jasmani pada anak usia 12-24 tahun (tesis).Program Pascasarjana Magister Ilmu Biomedik. Universitas Diponegoro Semarang;2007. 